\title{
Academic leaders' perspectives on adopting ePortfolios for developing and assessing professional capabilities in Australian business education
}

\author{
Dale Holt, \\ Deakin University, Melbourne, Australia \\ Nicholas McGuigan \\ Macquarie University, Sydney, Australia
}

Marie Kavanagh

University of Southern Queensland, Queensland, Australia

\author{
Shona Leitch \\ RMIT University, Melbourne, Australia
}

Leanne Ngo, Scott Salzman, Kim Watty, Jade McKay

Deakin University, Melbourne, Australia

\begin{abstract}
This paper represents a major stage of data collection and reporting on an Australian Office for Learning and Teaching Innovation and Development grant investigating the adoption of ePortfolios for developing and assessing professional capabilities in Australian undergraduate business education. Assessing desired capabilities with and through ePortfolios does not have strong traction in business education courses and disciplines. The status of ePortfolio use in business education in the sector is profiled through the perspectives of academic business leaders. The reasons why ePortfolio use is limited are explored, along with the possible benefits through greater and more systematic use in the curriculum. Various technological, training and support implementation issues are highlighted. The framing of key elements of effective implementation are summarised at the end of the paper.
\end{abstract}

\section{Introduction}

Hallam and Creagh (2010) observe that there is no single, straightforward definition of what an ePortfolio is in higher education, or even agreement on the use of the term itself, and that any definition is very much dependent on the context of application. For the purposes of this project, an ePortfolio is seen as a systematic collection and presentation of artefacts and reflections that is curated and managed by the learner as evidence of their learning and accomplishments, as well as a representation of learners' personal and professional identities. ePortfolios could also be used for evaluating coursework, assessment, professional and personal achievements, career development and employability. With the Internet gaining momentum in the 1990s, as well as advancements in learning technology, the way was paved for digital or online portfolios, hence the term ePortfolios. The "e" in ePortfolios offers learners dynamic development of their paper-based portfolio in a digital space by supporting learners' multimedia expression, promoting digital literacy, making learning visible and facilitating social pedagogy. Learners can easily curate digital artefacts of their learning and achievements, through learner-centred multimedia, sharing their portfolios with others online.

The use of ePortfolios has a strong history in the design professions and vocations, the creative and visual arts, healthcare professions for example nursing and midwifery (Andre \& Heartfield, 2011; Lillyman \& Merrix, 2012; Reed, 2011), and teacher education (Allan \& Cleland, 2012; Lee \& Pohio, 2012). It is standard practice that ePortfolios are required to facilitate and showcase creative learning artefacts in the design disciplines for assessment, course admission and job application. Evidence of ePortfolio use in Australian higher education can also be seen in engineering (Faulkner, Aziz, Waye, \& Smith, 2013), law (Faulkner et al., 2013; Waye \& Faulkner, 2011), construction (Williams, Simmons, Levett-Jones, Sher, \& Bowen, 2012), music education (Taylor, Dunbar-Hall, \& Rowley, 2012) and the sciences (Coleman et al., 2012). ePortfolio adoption can also focus more generally at the institutional level (Coffey \& Ashford-Rowe, 2014; Harper, McCowan, Hauville, Moody, \& Chorazyczewski, 2007; Lambert \& Corrin, 2007), faculty level (Swan, 2009), sectoral level (Joyes, Gray, \& Hartnell-Young, 2010) and in the context of a specific 
aspect of the curriculum like work-integrated learning (Shroff, Trent, \& Ng, 2013). Most of these studies foreground the perspectives of teachers using, and students engaging with, ePortfolios.

While ePortfolio studies seem voluminous, there appears to be little documented on the use of ePortfolios in the multi-disciplinary field of business studies, although the potential value was mentioned in the Australian Business Deans Council (ABDC) Scoping Report (2008). The paucity of reported work on ePortfolio use in business education was flagged by Housego and Parker (2009). An exception is the use of ePortfolios in business communication to enhance student employability (Okoro, Washington, \& Cardon, 2011) and in a professional development subject in business studies, again primarily to aid graduate recruitment (Woodley \& Sims, 2011). Consistent with the tenets of constructive alignment (Biggs \& Tang, 2011), assessment tasks and their elicited student performance responses, as enabled by ePortfolios, can only be as powerful as the learning outcomes they are intended to address. Pedestrian learning outcomes will be aligned to pedestrian teaching/learning activities and pedestrian assessment tasks. Constructive alignment may be achieved; however, the constructed learning artefacts of students will fail the potential of ePortfolio in the professional curriculum, both in form and substance.

This paper, with its distinctive focus on the general field of business education, examines academic business leaders' perspectives about the benefits and limitations of adopting ePortfolios for developing and assessing professional capabilities in the field of Australian undergraduate business education. These perspectives were elicited through the surveying of key categories of business academic leadership. The survey data were collected as part of a major 2-year nationally funded project on realising the potential of ePortfolios in the business education field. The aim of the survey was to generate baseline data on the current status of ePortfolios for assessing valued professional capabilities, or attributes or threshold learning outcomes, in business education and its constituent disciplines. While ePortfolios and their more recent migration to online platforms have been a longstanding educational approach in many professional fields, their use in business education has been more limited. Applications are often local and scattered in nature across the business education curriculum. The project to which this survey belongs investigates and promotes a more strategic course- and discipline-wide approach to the adoption of ePortfolios for developing and assessing professional capabilities. The leadership perspectives reported show that this will be a major curriculum undertaking. The key implication of the survey findings is the need for a framework to guide the good use of ePortfolios in business education. The key elements of such a framework are outlined in the paper.

\section{Background: Scoping the field of business education}

In defining the scope of potential ePortfolio implementation in business education, the field itself must be clearly understood. The ABDC has identified, through its academic standards development work and scholarly publication categories, the major business disciplines that constitute business education in the Australian higher education sector, namely: accounting (Freeman, 2010); marketing (Australian Business Deans Council [ABDC], 2012); finance (ABDC, 2014); economics (ABDC, 2013); tourism, hospitality and events (Whitelaw, Benckendorff, Gross, Mair, \& Jose, 2015); information systems; management; and business and taxation law. The ABDC is aiming to complete threshold learning outcome (TLO) statements for all relevant disciplines in business education.

The business component of business education, therefore, is diverse and eclectic. Certain disciplines like accounting, marketing and human resources management in business education can be specialised businesses in themselves offering services to other business organisations. They are also discernible functional departments (along with in-house legal services) in larger business organisations. Accounting has all the hallmarks of a well-established profession in its own right with clearly articulated accreditation (now based on TLOs) and admission requirements, along with continuing professional development expectations. Other fields like marketing have myriad relevant associations that graduates can be members of, but no mandated accreditation by, and admission requirements to, any one of them. The Australian Marketing Institute (AMI) provides an optional accreditation process for university and vocational education training (VET) providers. The general field of management studies requires adaptation to the various management and leadership challenges of different sectors, industries, types of business organisation, and unique businesses with their own missions, visions and product lines within both a strategic or operational focus.

Fundamentally, business education as a broad field of various studies is distinctive and different from highly structured, single purpose, homogeneous professions like law, engineering (even with its various branches 
of practice), architecture, medicine, nursing, midwifery and numerous other healthcare professions, and teacher education (again even with its various domains of educational practice, that is, pre-school, primary, secondary, vocational and higher education). It is readily apparent within all these other professions that their declared purposes at least are clear and focused; that is, to produce lawyers, engineers, architects, doctors, nurses, midwives, teachers, etc. Moreover, they all have well-articulated standards of professional practice which must be demonstrated for admission, regulatory frameworks around ongoing practice, and mandatory continuing professional requirements to retain registration-to-practice status. For those who opt for business education, there are many types of graduates that might be produced to contribute in many ways to business organisations. Accounting represents the exception within business education, where accounting majors are designed to produce accountants, with a number of sub-branches of practice available for the qualified accounting graduate. A secondary example is human resources management, which has accreditation and continuing professional development (CPD) requirements through the Australian Human Resources Institute (AHRI), and where graduates may move into human resource managerial positions.

Finally, information communications technology (ICT) including information systems (IS) degrees in Australia most commonly seek accreditation from the Australian Computer Society (ACS). The ACS uses the skills framework for the information age (Australian Computer Society, 2013) as the foundation for their accreditation and professional standards. This brings an international framework and understanding to standards in the Australian ICT discipline and provides a clear focus on the skills and levels of competency required by IS professionals in the business education domain.

\section{Context of challenges in business education}

The ABDC Scoping Report (2008) investigated, through the ABDC Teaching and Learning Network, existing resources, strengths, gaps, and challenges confronting business faculties and their programs in the sector. One key challenge highlighted related to the appropriate use of ICTs in advancing learning and teaching in business education. In the context of large, diverse and dispersed student populations undertaking business education, and the high student-staff ratios and academic workloads of business educators, the selection and use of ICTs must be done cost-effectively, and in ways which are seen to generate real value for student learning and teaching. The above factors and points of dissatisfaction indicate that tokenistic technology add-ons will make little impact on students or staff. The adoption of ePortfolios, as a significant technology for educational purposes, must be cognisant of this challenge. With the introduction of ePortfolio as educational technology is the possibility of influencing the way students fundamentally think about themselves, their professional identity, their sense of professionalism, and their unique capabilities to secure and excel in graduate employment.

Moreover, external developments around standard setting through the above TLO developments in business education disciplines, national and international professional accreditation and admission requirements, and the Tertiary Education Quality and Standards Agency (TEQSA) Australian Qualification Framework (AQF) guidelines, clearly are shaping the design of business education curricula. Specifically, on the international front are the European Quality Improvement System (EQUIS) and the Association to Advance Collegiate Schools of Business (AACSB). The potential role of ePortfolios in the assessment of TLOs and in generating evidence of valued learning being achieved for external accreditation is also a significant consideration.

Aside from the direct value of ePortfolios for learning and teaching enhancement, the role they might play in demonstrating that required learning has been achieved in meeting various external accountability and performance imperatives is a strategically important question to address. The extent to which they might demonstrate levels of performance beyond minimally stipulated threshold learning outcomes to help provide competitive employability advantage in the graduate employee recruitment market is as significant. These recruitment markets may also differ across rural, regional and major metropolitan settings, and the associated locations and spheres of influence of business faculties operating in these different geographic spaces. The Australian ePortfolio project (2009) promoted the value of ePortfolios in helping students prepare for graduate employment, and expanded their remit to include the value for employers in the human resource management functions of performance appraisal, training, career planning and continuing professional development. Again, in the US context, Hart Research Associates (2013) found that more than four in five employers said an ePortfolio would be helpful to them in ensuring that job applicants have the capabilities needed to succeed in their organisation. 


\section{Purpose of ePortfolios in business education and location within internal and external environments}

The project has situated the purpose of ePortfolios in business education in relation to various internal and external factors that are shaping the field (see Figure 1).

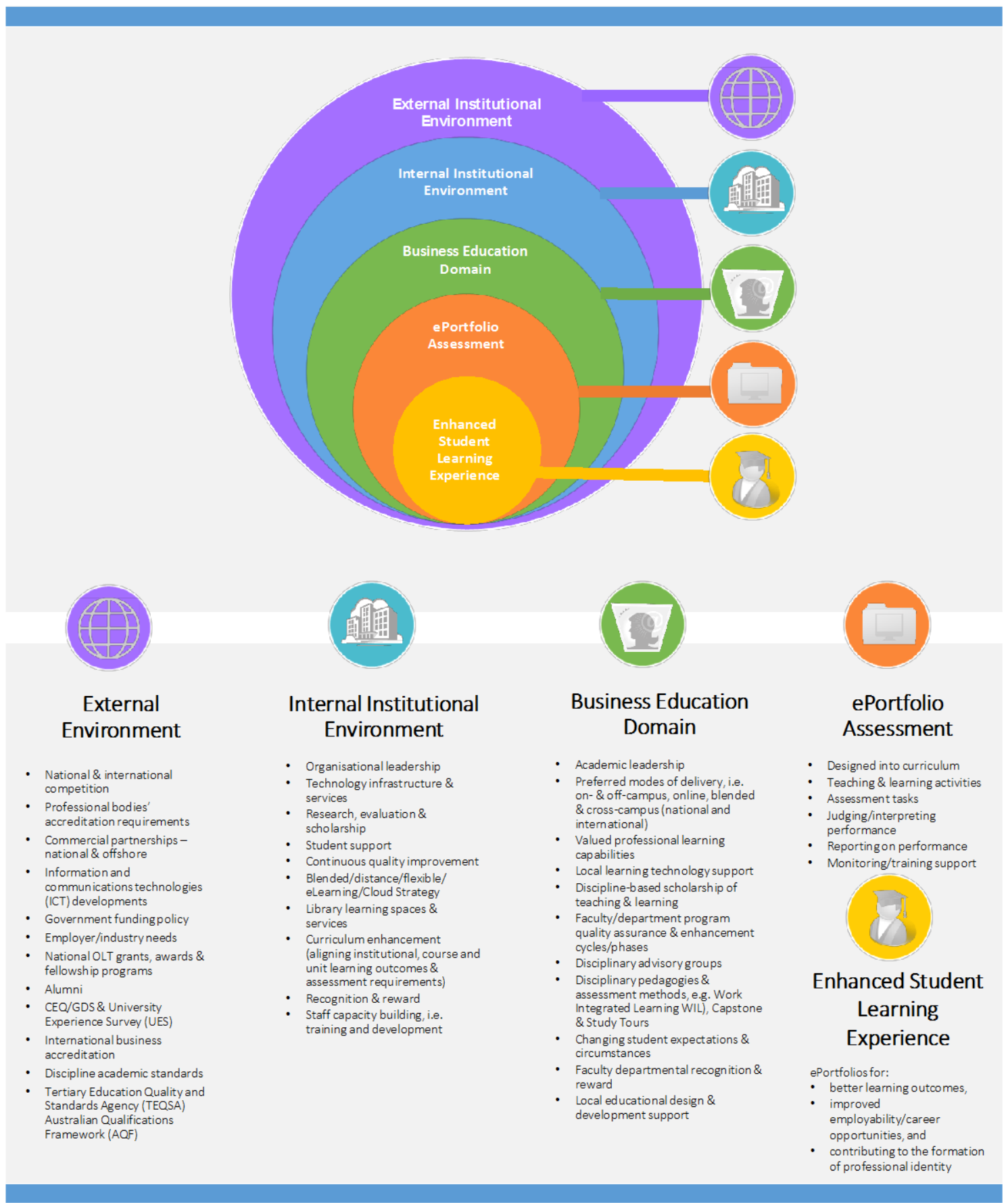

Figure 1. Constellation of external and internal environmental factors impacting ePortfolio adoption in business education (Ngo et al., 2014)

ePortfolios provide an opportunity for enhancing and evidencing learning experiences and outcomes, professional identity and judgement making, employability and career development. In order to achieve these benefits, ePortfolio design and implementation must take account of the myriad factors shaping its effective integration within the field, both within the institution and its external environment. 


\section{Research methodology}

\section{Staging the national project and data collection methods}

The national project is being conducted over 2 years (July 2013-July 2015) using a multi-stakeholder, mixed methods and multi-case-study site approach. A survey of academic leaders formed the key first stage of data collection in the first year of the project. Other data collection methods and activities have encompassed:

- $\quad$ selected interviews with employers regarding their understanding of ePortfolios and their potential value and use in graduate recruitment and selection;

- identification of valued professional capabilities in business education through analysis of business education discipline TLOs, institutional statements of graduate attributes and associated statements of course learning outcomes;

- development of ePortfolio case study interventions in the different partner institutions' business education contexts;

- planning the research of these case study interventions on the learning and teaching experience through focus groups and interviews; and

- incremental formulation of a framework for the effective design and practice of ePortfolios for assessment in business education, with feedback from various parties on its relevance and value in enhancing constructive use through national forums, the project reference group and expert independent evaluator contributions.

This paper focuses on the presentation of the academic leaders' survey responses on the status and potential value of ePortfolios in the field. Employer perspectives will be examined in a separate planned publication.

\section{Identifying and defining valued professional capabilities in business education}

Assessment with and through ePortfolio must be clearly anchored in relation to the major goals of learning in business education, hereby referred to as valued professional capabilities. The project team identified from its analysis of business discipline threshold learning outcome statements, and relevant institutional graduate and course learning outcomes, the following 13 professional capabilities that could form the basis of enhanced development and assessment with and through ePortfolio adoption:

1. Professional judgement: Use knowledge and skills to solve novel business challenges.

2. Problem solving: Use knowledge and skills to identify and solve common business problems.

3. Communication: Demonstrate oral, written and visual communication skills appropriate to the needs of different business stakeholders.

4. Teamwork: Demonstrate skills in working collaboratively with colleagues in undertaking complex and varied work tasks.

5. Leadership: Demonstrate skills in constructively influencing the work of colleagues individually and in teams towards mutually agreed goals.

6. Digital literacy: Use knowledge and skills in ICT to frame, analyse and report on business problems and their solutions.

7. Self-management: Demonstrate skills in self-initiative, self-motivation and self-directed learning in business studies and practices.

8. Creativity and innovation: Demonstrate the capacity to generate new ideas to meet customer needs, and in the understanding of how good ideas become marketable products.

9. Entrepreneurship: Appreciate how new businesses are created, grow and adapt to changing market conditions.

10. Social responsibility: Develop a critical awareness of businesses' obligations to the societies within which they operate, and to those parties who directly contribute to their viability.

11. Cultural awareness: Demonstrate knowledge and skills in working effectively with cultural diversity as related to global and international business practices.

12. Sustainability as applied to business organisations: Develop a critical awareness of businesses’ need to evolve and adapt to the imperatives of an economically, environmentally and socially sustainable world in the service of future generations. 
13. Ethics: Develop a personally meaningful set of values to guide professional practice which reflect honesty, fairness, respectfulness, loyalty, composure and competence.

\section{Survey design and administration}

The business academic leaders' ePortfolio survey design was informed by three major literature reviews conducted within the project, encompassing developments in business education, major learning and assessment issues relating to the use of ePortfolios, and key technical concerns in using the ePortfolio as an effective educational technology. Certain survey items were adapted from a national surveying undertaken as part of previous nationally funded ePortfolio grant projects in the Australian higher education sector (Australian ePortfolio Project, 2008, 2009). The survey went through an iterative design process receiving multiple rounds of feedback from the project team, with input from the project reference group and the project's independent senior evaluator. The survey was produced in the freeware Qualtrics online survey tool. The design and functioning of the survey in the online format was checked by the project team, with a trial run of the survey online completed by team members and a small selection of the targeted leaders before it was launched for completion by the targeted academic leadership group in the sector. The survey and its process of administration received ethics clearance from the lead institution's Faculty Ethics Committee.

The respondent target group was organised primarily through the ABDC Teaching and Learning Network Chair. The ABDC Network is composed of Australian Business Faculty/School Associate Deans, Teaching and Learning (or equivalent). The associate deans were invited via the chair of the network to complete the survey directly, and to supply the names of five interested or experienced staff (in the ePortfolio domain) who could be targeted for survey completion. These names were returned to the project team for action. The principal academic leadership categories targeted were: associate dean, teaching and learning (or equivalent); program/course director; and subject/course/unit chair. In addition, the project team identified academic leadership of direct relevance in their respective institutions for survey completion. Furthermore, a specific group of business educators was targeted at a major discipline conference. An online survey of 100 academic leaders of business courses was carried out and a total of 54 usable responses were received; representing a response rate of $54 \%$ against the number of surveys administered. The survey process was administered between March and July 2014.

Through these avenues, the project team aimed to achieve a broad and strong range of perspectives on the status of ePortfolio development and use in the business education sector. Having said this, the project team recognise the limitations inherent in drawing conclusions about a population where all members of that population do not have the same probability of being selected in the sampling frame. Academic leaders who provided their opinions were asked to do so because they were known to be significant contributors to business education within their educational institutions. The survey administration elicited responses from staff outside the three areas of formally designated academic leadership. As academics with an interest in or experience of ePortfolios, these respondents might be seen as business education leaders.

All 54 responses received for survey items were analysed. Not all respondents completed all sections of the survey. A number of respondents only completed the first part of the survey, as they were not in a position to respond to questions relating specifically to ePortfolio experiences in their particular business education context. Furthermore, the survey was designed to allow those with no experience of ePortfolios to exit the survey at a designated point.

\section{Survey analysis method}

There is no recognised method to evaluate the expert authority used to identify the sample selected and the potential of this sampling method to reduce sampling error to make sweeping statements cannot be supported. However, the objective of this research is not to make generalisations, but rather to discuss the complexities of the responses provided and identify areas for future investigation. In the analysis, all error presented is representative of a 95\% confidence interval for parameters of interest. Where necessary, the chi-square goodness of fit test was used. To assess for differences between more than two means, the oneway analysis of variance test was used and where necessary, post hoc tests were assessed using a $t$-test. For simple comparisons of means, the student's $t$-test was used. Where assumptions required for any parametric statistical analysis were not met, summary analysis only is presented and subsequent comment provided or, 
non-parametric analogues are used. For example, the Kruscal-Wallis comparisons of medians test was used as a surrogate for the one-way analysis of variance test, with the Mann-Whitney difference between medians test used for subsequent post hoc analysis. For some questions, respondents were able to mark "as many [factors] as apply”. For these types of questions, all marked items were accorded the same weight. In the data matrix, Qualtrics recorded data in an unusual way for some questions, for example, assigning numerical rank order codes as: 2 strongly disagree, 3 disagree, 4 neutral, 5 agree and 6 strongly agree. Further, some rank order codes were not recorded sequentially, for example: 2 unimportant, 3 somewhat important, 5 important and 6 very important. All rank order data were recoded with a base rank of 1, and ranks sequentially numbered thereafter. Notes on recoded responses are included where appropriate.

\section{Sample background}

There were 54 responses to the question of respondent's leadership role. Nine respondents indicated "other" than the three key categories stipulated. Of the staff who had some form of a leadership role, $46.3 \%$ indicated that they were "subject/course/unit chair" personnel. Regarding the respondents' universities, $58.8 \%$ of all responses came from five universities: La Trobe University [LATROBE] $(n=6)$, Deakin University [Deakin] $(n=6)$, University of Tasmania [UTAS] $(n=6)$, Federation University $(n=5)$ and Griffith University [GRIFFITH] $(n=7)$. Most responses came from innovative research universities and non-aligned universities (29\% of all responses in each group, respectively). With respect to their disciplinary background, as the audience of a discipline-specific conference was targeted during sampling, a high proportion of respondents (43.9\%) were accountants. Regarding length of time spent in leadership roles, $48.15 \%$ of respondents indicated that they had been in their current role for more than 5 years. In addition, $37.7 \%$ of respondents indicated that they had been involved in university business education for more than 20 years. Results indicate that most respondents (66\%) were likely to have had at least 10 years of experience. Finally, most universities predominantly used the on-campus mode of delivery, with $46.3 \%$ of responding universities indicating this.

\section{Findings}

\section{Rating the importance of and satisfaction with professional capabilities}

Professional capability development and assessment is a cornerstone of efforts to enhance the adoption of ePortfolios in business education. Academic leaders were asked to rate the importance of each professional capability and satisfaction with its development and achievement in their context. Based on leader ratings, Tables 1 and 2 (and associated bar graph visual representations located directly underneath each table below as Figures 2 and 3), respectively, present rankings of the importance of professional capabilities and satisfaction of their achievement in descending order from highest to lowest.

In descending order of importance, two factors, Communication and Problem solving, were rated significantly higher by respondents than all other factors, with the exception of Professional judgement (Problem solving was not significantly different to Professional judgement). Also, Entrepreneurship is significantly lower than any of the other estimated factors. Compared to academic leaders from all other backgrounds combined who responded, accountants are less likely to see the importance of Creativity and innovation. In descending order of satisfaction, on average, academic leaders are only likely to be somewhat satisfied (median rank) that the professional learning capability factors are being effectively developed and assessed within their educational institutions. Specifically, Problem solving is seen as likely to be more effectively developed and assessed when compared to most other professional learning capability factors. On the other hand, when compared to several other professional learning capability factors, it is possible that Creativity and innovation is seen as being the least effectively developed and assessed factor. In summary, although appreciating the limitations in comparing importance and satisfaction, it can be seen that for all attributes measured, it appears that academic leaders are not convinced that the level of importance placed on any one of those attributes is being satisfactorily met. 
Table 1

Professional capabilities ranked and presented in descending order of importance

\begin{tabular}{|l|l|c|c|c|c|c|c|c|c|c|}
\hline Rank & $\begin{array}{l}\text { Importance of } \\
\text { professional learning } \\
\text { capability factor to } \\
\text { business education }\end{array}$ & $\boldsymbol{N}$ & $\boldsymbol{M}$ & $\boldsymbol{S D}$ & Skew & Min & Q1 & Median & Q3 & Max \\
\hline & All & & & & & & & & \\
1 & Communication & 584 & 3.29 & 0.77 & -0.78 & 1 & 3 & 3 & 4 & 4 \\
2 & Problem solving & 45 & 3.82 & 0.44 & -2.53 & 2 & 4 & 4 & 4 & 4 \\
3 & Professional judgement & 45 & 3.78 & 0.47 & -2.04 & 2 & 4 & 4 & 4 & 4 \\
4 & Self-management & 44 & 3.52 & 0.59 & -0.93 & 2 & 3 & 4 & 4 & 4 \\
5 & Ethics & 45 & 3.51 & 0.63 & -0.53 & 2 & 3 & 4 & 4 & 4 \\
6 & Teamwork & 45 & 3.47 & 0.63 & -0.74 & 2 & 3 & 4 & 4 & 4 \\
7 & Digital literacy & 45 & 3.27 & 0.75 & -0.49 & 2 & 3 & 3 & 4 & 4 \\
8 & Cultural awareness & 45 & 3.22 & 0.82 & -0.70 & 1 & 3 & 3 & 4 & 4 \\
9 & Leadership & 45 & 3.16 & 0.77 & -0.59 & 1 & 3 & 3 & 4 & 4 \\
10 & Social responsibility & 45 & 3.16 & 0.74 & -0.26 & 2 & 3 & 3 & 4 & 4 \\
11 & Creativity and innovation & 45 & 3.02 & 0.66 & -0.02 & 2 & 3 & 3 & 3 & 4 \\
12 & Sustainability as applied to & 45 & 2.89 & 0.78 & -0.41 & 1 & 2 & 3 & 3 & 4 \\
& business organisations & & & & & & & & & \\
13 & Entrepreneurship & 45 & 2.42 & 0.87 & 0.14 & 1 & 2 & 2 & 3 & 4 \\
\hline
\end{tabular}

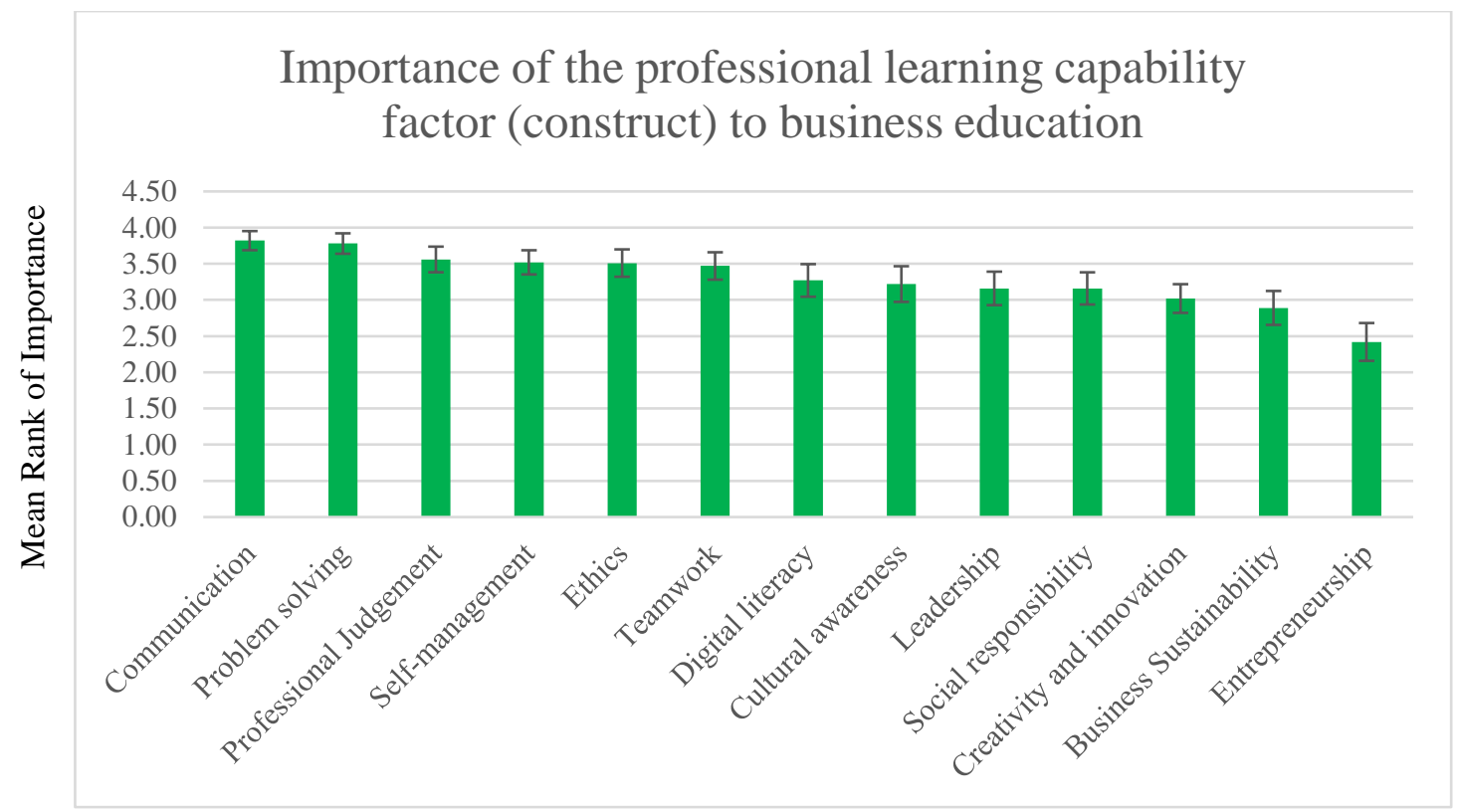

Importance Factor/Construct

Figure 2. Importance of the professional learning capability factor (construct) to business education Note: Error bars represent 95\% confidence interval estimates for the mean. 
Table 2

Professional capabilities ranked and presented in descending order of satisfaction

\begin{tabular}{|c|c|c|c|c|c|c|c|c|c|c|}
\hline Rank & $\begin{array}{l}\text { Satisfaction that this } \\
\text { professional learning } \\
\text { capability factor is } \\
\text { being developed and } \\
\text { assessed appropriately }\end{array}$ & $N$ & $M$ & $S D$ & Skew & Min & Q1 & Median & Q3 & Max \\
\hline & All & 567 & 2.08 & 0.80 & 0.21 & 1 & 1 & 2 & 3 & 4 \\
\hline 1 & Problem solving & 43 & 2.53 & 0.70 & 0.09 & 1 & 2 & 3 & 3 & 4 \\
\hline 2 & Digital literacy & 44 & 2.30 & 0.79 & -0.01 & 1 & 2 & 2 & 3 & 4 \\
\hline 3 & Communication & 44 & 2.27 & 0.69 & -0.43 & 1 & 2 & 2 & 3 & 3 \\
\hline 4 & Teamwork & 44 & 2.18 & 0.84 & -0.12 & 1 & 2 & 2 & 3 & 4 \\
\hline 5 & Ethics & 44 & 2.14 & 0.93 & 0.26 & 1 & 1 & 2 & 3 & 4 \\
\hline 6 & Self-management & 43 & 2.12 & 0.82 & -0.22 & 1 & 1 & 2 & 3 & 3 \\
\hline 7 & $\begin{array}{l}\text { Sustainability as applied } \\
\text { to business organisations }\end{array}$ & 44 & 2.09 & 0.77 & 0.16 & 1 & 2 & 2 & 3 & 4 \\
\hline 8 & Social responsibility & 44 & 2.02 & 0.82 & 0.49 & 1 & 1 & 2 & 2 & 4 \\
\hline 9 & Professional judgement & 43 & 2.00 & 0.72 & 0.40 & 1 & 2 & 2 & 2 & 4 \\
\hline 10 & Cultural awareness & 44 & 1.98 & 0.85 & 0.52 & 1 & 1 & 2 & 2 & 4 \\
\hline 11 & Entrepreneurship & 42 & 1.88 & 0.77 & 0.55 & 1 & 1 & 2 & 2 & 4 \\
\hline 12 & Leadership & 44 & 1.82 & 0.76 & 0.66 & 1 & 1 & 2 & 2 & 4 \\
\hline 13 & $\begin{array}{l}\text { Creativity and } \\
\text { innovation }\end{array}$ & 44 & 1.68 & 0.67 & 0.48 & 1 & 1 & 2 & 2 & 3 \\
\hline
\end{tabular}

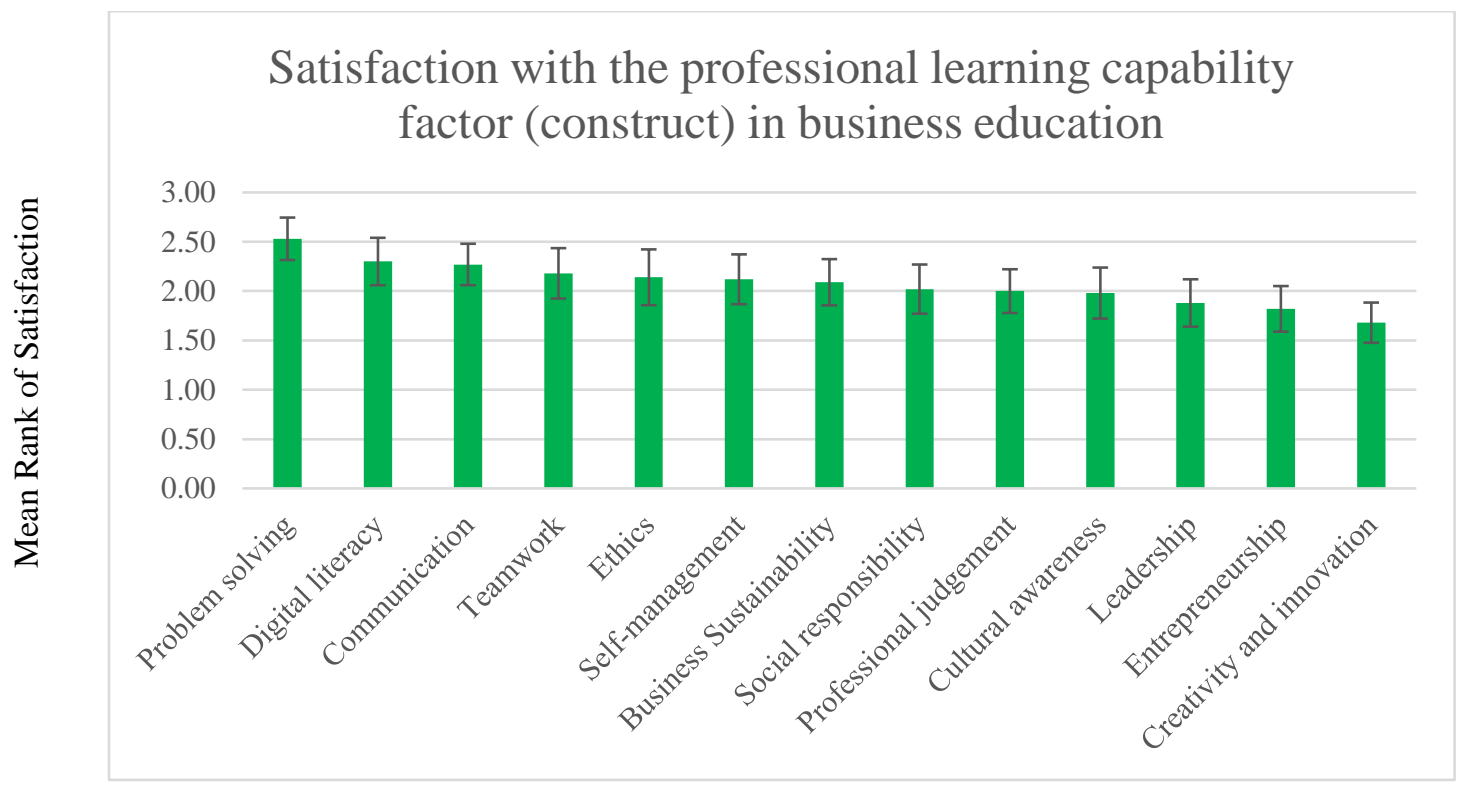

Importance Factor/Construct

Figure 3. Satisfaction with the professional learning capability factor (construct) in business education Note: Error bars represent 95\% confidence interval estimates for the mean.

\section{Key pedagogies used in developing and assessing professional capabilities}

Key pedagogies commonly mentioned by respondents that could be used in developing and assessing professional capabilities are:

1. Problem solving: Ranked in order of decreasing importance, respondents indicated: 1 . Case studies; 2. Projects; 3. Work-placement; and 4. Simulations, might be effective ways to assess a student's ability to solve problems.

2. Communication: Case studies, projects, presentations and written work appear to be the most favoured ways to assess a student's ability to communicate. 
3. Teamwork: Group projects and work placements appear to be the most favoured ways to assess a student's ability to work in a team.

4. Leadership: Projects appear to be the most favoured ways to assess a student's ability to lead a team.

5. Digital literacy: Projects, simulations and assignments appear to be the most favoured ways to assess a student's digital literacy.

6. Self-management: Projects and work placements appear to be the most favoured ways to assess a student's ability to self-manage.

7. Creativity and innovation: Projects appears to be the most favoured way to assess a student's creativity and innovation.

8. Entrepreneurship: Projects perhaps within a business context appears to be the most favoured way to assess a student's entrepreneurial skills.

9. Social responsibility: Projects and Case studies appear to be the most favoured ways to assess a student's sense of social responsibility.

10. Cultural awareness: International study and work tours appear to be the most favoured ways to assess a student's cultural awareness.

11. Business Sustainability: Case studies, work placements and projects appear to be the most favoured ways to assess a student's understanding of sustainability in a business context.

12. Professional judgement: Case studies, work placements and simulations appear to be the most favoured ways to assess a student's professional judgement skills.

13. Ethics: Case studies and projects appear to be the most favoured ways to assess a student's understanding of ethics.

\section{Current use of ePortfolios in business education and reasons for non-use}

In relation to the scope of use of ePortfolios in the respondents' business education context, $54.7 \%$ of respondents either don't know or do not use an ePortfolio. A number of reasons were given by respondents for not using ePortfolios. The first of these was the lack of an institutional strategy and culture conducive to the use of ePortfolios. Second, there is a heavy reliance on traditional modes of program design, delivery and assessment and the associated requirements of time and energy to switch to something different to embed ePortfolios effectively are too great. Third, there is a lack of knowledge about ePortfolios and their benefits amongst teaching staff, and a lack of support for their use. Fourth, traditionally structured curricula and pedagogies do not allow across course use of ePortfolios and unit credits, which would be required to make the effort of implementing them worthwhile. Fifth, there is a lack of provision of robust ePortfolio technology solutions to make use easy and effective. Sixth, there is only small local unit-based use of ePortfolios and Portfolios used in traditional paper-based form. Seventh, there is a lack of understanding about whether ePortfolios would be a good mechanism for evidencing the achievement of unit learning outcomes. Finally, there is a general sense of multiple points of resistance to the use of ePortfolios amongst staff, students, professional bodies and the institution, and lack of evidence about the value of ePortfolios.

\section{Views on the nature of ePortfolios}

Four common views on the nature of ePortfolios were presented to academic leaders. Each one resonated with their understanding and experience. First, an ePortfolio is a secure repository for students to collect and store evidence of their skills and knowledge attainment. Most people (87.5\%) agreed with this statement; $4.2 \%$ of respondents strongly disagreed. Second, an ePortfolio is a place for students to reflect upon their learning journey - where they have come from and where they are going to - in other words, the process of learning. Most people (95.8\%) agreed or somewhat/slightly agreed with this statement. We found nobody who strongly disagreed. Third, ePortfolios are evidence of skills, but there is also an opportunity to show the process and to reflect on what this means to the student. Most people (91.6\%) agreed with this statement, and no-one strongly disagreed. Finally, ePortfolios are about reflecting on learning, but there is also the opportunity to collect and attach some evidence for this. Most people (91.6\%) agreed with this statement, and no-one strongly disagreed.

\section{Technologies used in implementing ePortfolios and their effectiveness}

PebblePad is the most common type of technology used in the business education context, accounting for $38.5 \%$ of all users. In addition, 46\% of respondents use Microsoft tools (MSWord and MSPowerPoint), 
with $46 \%$ also using social networking tools. Regarding the effectiveness of an ePortfolio technology solution, $57 \%$ of respondents indicated that the functions of their ePortfolio solution are at least somewhat effective in achieving their education purposes; 39\% indicated that they are unsure; and only 4\% indicated that they are not effective. No respondents indicated that they were very effective.

\section{Perceived drivers of ePortfolio use}

Drivers of ePortfolio use are listed in descending order of importance in Table 3.

Improving student reflective learning is seen as being significantly more important than most other factors, whereas "the imperative to use the technology given the nature of the institution" is seen as being significantly less important than many other factors. "Allow students to better demonstrate the achievement of learning outcomes” and "enhancing student work placement experience” are also seen as being significantly more important than many other factors by academic leaders.

Table 3

Ranking of importance of drivers of ePortfolio use

\begin{tabular}{|c|c|c|c|c|c|c|c|c|c|c|}
\hline Rank & $\begin{array}{l}\text { Drivers/factors contributing } \\
\text { to the implementation of } \\
\text { ePortfolios }\end{array}$ & $N$ & $M$ & $S D$ & Skew & Min & Q1 & Median & Q3 & Max \\
\hline & All & 248 & 2.90 & 0.92 & -0.43 & 1 & 2 & 3 & 4 & 4 \\
\hline 1 & $\begin{array}{l}\text { Improve student reflective } \\
\text { learning }\end{array}$ & 22 & 3.55 & 0.51 & -0.20 & 3 & 3 & 4 & 4 & 4 \\
\hline 2 & $\begin{array}{l}\text { Enhance student work } \\
\text { placement experience }\end{array}$ & 21 & 3.38 & 0.67 & -0.63 & 2 & 3 & 3 & 4 & 4 \\
\hline 3 & $\begin{array}{l}\text { Allow students to better } \\
\text { demonstrate the achievement } \\
\text { of learning outcomes }\end{array}$ & 22 & 3.32 & 0.72 & -0.57 & 2 & 3 & 3 & 4 & 4 \\
\hline 4 & $\begin{array}{l}\text { Improve student } \\
\text { understanding of learning } \\
\text { outcomes }\end{array}$ & 22 & 3.18 & 0.85 & -0.88 & 1 & 3 & 3 & 4 & 4 \\
\hline 5 & $\begin{array}{l}\text { Enable students to integrate } \\
\text { their learning across } \\
\text { subjects/units }\end{array}$ & 20 & 3.10 & 0.91 & -0.68 & 1 & 2.8 & 2 & 4 & 4 \\
\hline 6 & $\begin{array}{l}\text { Enable students to integrate } \\
\text { their learning within } \\
\text { subjects/units }\end{array}$ & 20 & 3.05 & 0.83 & -0.10 & 2 & 2 & 3 & 4 & 4 \\
\hline 7 & $\begin{array}{l}\text { Allow more varied forms of } \\
\text { assessment using different } \\
\text { media formats }\end{array}$ & 22 & 2.95 & 0.84 & 0.09 & 2 & 2 & 3 & 4 & 4 \\
\hline 8 & $\begin{array}{l}\text { Allow the better recognition of } \\
\text { prior learning }\end{array}$ & 22 & 2.50 & 0.74 & -0.39 & 1 & 2 & 3 & 3 & 4 \\
\hline 9 & $\begin{array}{l}\text { Demonstrate achievement of } \\
\text { TEQSA AQF requirements }\end{array}$ & 20 & 2.50 & 1.00 & -0.18 & 1 & 2 & 3 & 3 & 4 \\
\hline 10 & $\begin{array}{l}\text { Employer demands as part of } \\
\text { recruitment and selection }\end{array}$ & 18 & 2.44 & 0.86 & 0.19 & 1 & 2 & 2 & 3 & 4 \\
\hline 11 & $\begin{array}{l}\text { Demonstrate assurance of } \\
\text { learning for international } \\
\text { business accreditation }\end{array}$ & 20 & 2.40 & 0.75 & -0.85 & 1 & 2 & 3 & 3 & 3 \\
\hline 12 & $\begin{array}{l}\text { The imperative to use } \\
\text { technology given the nature of } \\
\text { the institution, i.e. mission, } \\
\text { vision etc. }\end{array}$ & 19 & 2.16 & 1.12 & 0.45 & 1 & 1 & 2 & 3 & 4 \\
\hline
\end{tabular}




\section{Assessment activities in ePortfolios}

Learning activities reviewed or assessed in the ePortfolio context are shown in Figure 4 below.

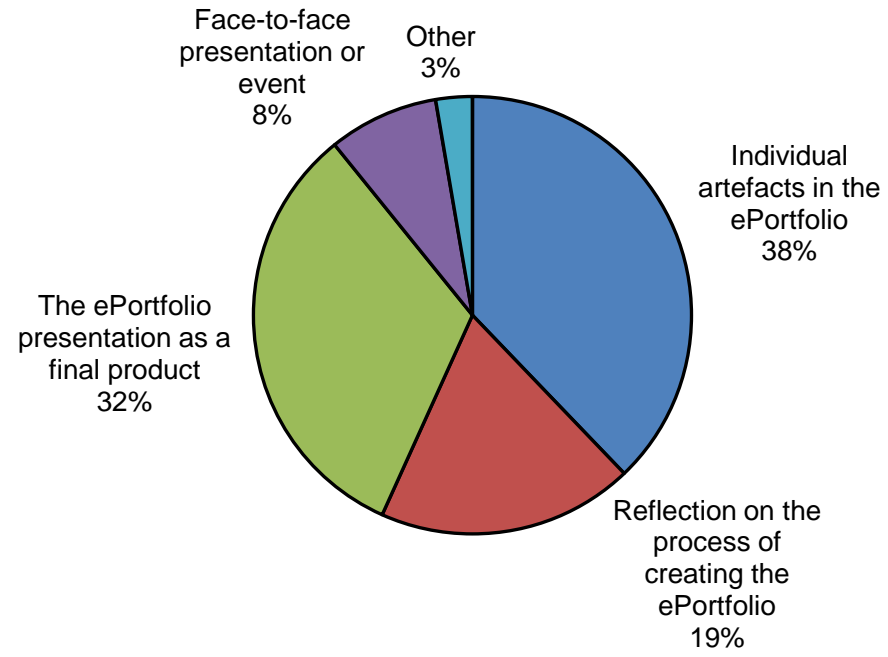

Figure 4. Learning aspects assessed in ePortfolio

In relation to who reviews or assesses in an ePortfolio context, respondents indicated that teachers or tutors are more likely to be involved in the ePortfolio assessment process compared to any of the other review or assessment processes considered (50\% in the sample).

\section{Supporting and guiding teaching staff and students in using ePortfolios effectively}

In relation to guidance and support for students in using ePortfolios effectively, there was insufficient evidence available to detect a difference between the six types of guidance and support considered based on analysis of leadership responses to this question, namely: guidance on the purpose of the ePortfolio; guidance on how to use the ePortfolio; a workshop alongside to support the ePortfolio process; tutor/mentor support; IT helpdesk support for the learner; and support for producing media files. That is, it cannot be said that one type of guidance and support mechanism is more or less useful than another when considering how they helped assist students gain benefits from the ePortfolio system. All guidance and support mechanisms are considered, on average, as somewhat useful to very useful.

In relation to guidance and support for teaching staff in using ePortfolios effectively, there was insufficient evidence available to detect a difference between the seven types of factors considered by academic leaders, namely: guidance on the purpose of the ePortfolio; guidance on how to use the ePortfolio; a workshop alongside to support the ePortfolio process; tutor/mentor support; IT helpdesk support for the teacher; support for producing media files; and seeing and discussing exemplars. That is, it cannot be said that one type of guidance and support factor is more or less useful than another when considering how the factors assist in helping gain benefits. On average, these factors are considered useful. Academic leaders who responded indicated that they believe the ePortfolio guidance and support factors are, on average, more useful for the student than the teacher.

\section{Perceived positive impacts of ePortfolios for teaching staff and students}

Academic leaders' perceptions of staff and student awareness of the teaching and learning impacts of using ePortfolios in their contexts are presented in Tables 4 and 5, respectively. 
Table 4

Leaders' perceptions of staff awareness of impacts

\begin{tabular}{|l|c|c|c|c|c|c|c|c|c|}
\hline Awareness Statement & $\boldsymbol{N}$ & $\boldsymbol{M}$ & $\boldsymbol{S D}$ & Skew & Min & Q1 & Median & Q3 & Max \\
\hline All & 93 & 3.52 & 1.01 & -1.12 & 1 & 3 & 4 & 4 & 5 \\
$\begin{array}{l}\text { Increased staff awareness of } \\
\text { eLearning technology }\end{array}$ & 18 & 3.72 & 0.89 & -1.60 & 1 & 3.25 & 4 & 4 & 5 \\
$\begin{array}{l}\text { Increased staff awareness of } \\
\text { learning outcomes }\end{array}$ & 19 & 3.37 & 1.07 & -1.16 & 1 & 3 & 4 & 4 & 5 \\
$\begin{array}{l}\text { Increased staff awareness of } \\
\text { reflective learning }\end{array}$ & 19 & 3.84 & 0.90 & -1.72 & 1 & 4 & 4 & 4 & 5 \\
$\begin{array}{l}\text { Increased staff awareness of } \\
\text { graduate attributes } \\
\text { Increased staff awareness of } \\
\text { professional/industry skills }\end{array}$ & 19 & 3.32 & 1.06 & -0.72 & 1 & 3 & 3 & 4 & 5 \\
\hline
\end{tabular}

Table 5

Leaders' perceptions of student awareness of impacts

\begin{tabular}{|l|c|c|c|c|c|c|c|c|c|}
\hline Awareness Statement & $\boldsymbol{N}$ & $\boldsymbol{M}$ & $\boldsymbol{S D}$ & Skew & Min & Q1 & Median & Q3 & Max \\
\hline All & 87 & 3.78 & 1.06 & -1.16 & 1 & 3 & 4 & 4 & 5 \\
$\begin{array}{l}\text { Increased student awareness of } \\
\text { eLearning technology }\end{array}$ & 17 & 3.82 & 1.07 & -1.32 & 1 & 4 & 4 & 4 & 5 \\
$\begin{array}{l}\text { Increased student awareness of } \\
\text { learning outcomes }\end{array}$ & 18 & 3.89 & 0.96 & -1.53 & 1 & 4 & 4 & 4 & 5 \\
$\begin{array}{l}\text { Increased student awareness of } \\
\text { reflective learning }\end{array}$ & 18 & 3.94 & 1.00 & -1.47 & 1 & 4 & 4 & 5 & 5 \\
$\begin{array}{l}\text { Increased student awareness of } \\
\text { graduate attributes }\end{array}$ & 17 & 3.47 & 1.01 & -0.74 & 1 & 3 & 4 & 4 & 5 \\
$\begin{array}{l}\text { Increased student awareness of } \\
\text { professional/industry skills }\end{array}$ & 17 & 3.76 & 1.30 & -1.25 & 1 & 4 & 4 & 5 & 5 \\
\hline
\end{tabular}

Finally, academic leaders’ perceptions of awareness of other impacts are presented in Table 6.

Table 6

Leaders' perceptions of awareness of other impacts

\begin{tabular}{|l|c|c|c|c|c|c|c|c|c|}
\hline Statement & $\boldsymbol{N}$ & $\boldsymbol{M}$ & $\boldsymbol{S D}$ & Skew & Min & Q1 & Median & Q3 & Max \\
\hline All & 34 & 3.35 & 0.85 & -1.09 & 1 & 3 & 3 & 4 & 5 \\
$\begin{array}{l}\text { Increased goal setting/career } \\
\text { planning activity by students } \\
\begin{array}{l}\text { Improved assessment or review } \\
\text { process }\end{array}\end{array}$ & 17 & 3.47 & 0.87 & -1.17 & 1 & 3 & 4 & 4 & 5 \\
\hline
\end{tabular}

In relation to the impact of ePortfolios on raising teaching staff awareness of the benefits to their teaching, illustrated in Table 4 above, no difference was detected. That is, academic leaders indicated that staff should be similarly aware regarding each factor. Responding academic leaders indicated staff would, on average, agree with each statement. In relation to the impact of ePortfolios on raising student awareness of the benefits to their learning, illustrated in Table 5 above, no difference was detected. That is, the responding group of academic leaders indicated that students should be similarly aware regarding each factor. Further, they also indicated students should, on average, at least agree with each awareness statement and furthermore, that both staff and students should, on average, score similarly regarding these awareness statements. They both should, on average, at least agree with all awareness statements. In regards to the impact of ePortfolios on other benefits, illustrated in Table 6 above, academic leaders indicated a neutral (3 neutral) response for both of these other statements. 


\section{Implications}

Housego and Parker (2009) and Woodley and Sims (2011), reflecting on their respective investigations, conclude that ideally ePortfolios should be integrated appropriately into the whole curriculum. With this in mind, ePortfolio implementation for assessing professional capabilities can be seen in the context of: wholeof-program-based curriculum designs; the major disciplinary studies allowing specialisation in business degrees; key areas of the curriculum dealing with work-integrated learning (WIL) (see Papadopoulos, Taylor, Fallshaw, \& Zanko, 2011), foundational core and capstone studies, and those dealing directly with managerial capabilities like intrapersonal and interpersonal intelligence.

Opportunities for ePortfolio adoption in business education may be understood in the context of different types of curricula. Business education programs may:

- $\quad$ have a defined number of core subjects required to be studied at first and possibly second year level, building the foundational knowledge and skill set in understanding different aspects of business organisations, with a broad choice of specialised discipline majors which can then be taken and which in turn can lead students in many different career directions and employment opportunities (the general-plus-specialisation business education curriculum design model).

- $\quad$ have a greater number of mandated subjects within the broadly defined field of management studies with less choice and specialised disciplinary studies and with the focus on leading students into the many career and employment opportunities related to management practice (the generally focused management education curriculum design model).

- $\quad$ have a greater number of mandated subjects within the broadly defined field of specialisation of management studies (e.g. business information systems) with less choice and specialised disciplinary studies and with the focus on leading students into the many career and employment opportunities related to the designated specialised field of practice (the generally focused specialised business education curriculum design model).

While such curriculum structures and designs exist for high potential use of ePortfolios, academic business leader views show that ePortfolios are as yet not a major part of the business education technological landscape. In order to explain and promote their more significant and enhanced use the project team is formulating a guidance framework for effective implementation. The elements of the framework have been identified and are being elaborated on, based on application within the case studies, in the second year of the project. The framework is being formulated to address the findings of the academic leadership survey and other stakeholder perspectives, and is outlined in Table 7. 
Table 7

Framing assessment of and through ePortfolios in Australian undergraduate business education

\begin{tabular}{|c|c|c|}
\hline Framework background & The framework (key questions \& perspectives) & $\begin{array}{c}\text { Framework } \\
\text { resources }\end{array}$ \\
\hline $\begin{array}{l}\text { Purposes: learning and } \\
\text { employability } \\
\text { Context: internal \& external } \\
\text { environmental factors } \\
\text { Principles: for effective } \\
\text { design \& use irrespective of } \\
\text { context } \\
\text { Definition: nature \& added } \\
\text { value through using electronic } \\
\text { means } \\
\text { Stakeholders: students, } \\
\text { student societies, alumni, } \\
\text { teaching staff, levels of } \\
\text { academic leadership, learning } \\
\text { technology support staff, IT } \\
\text { departments, technology } \\
\text { suppliers, graduate careers } \\
\text { Benefits: see \& respond to } \\
\text { feedback, various media types } \\
\text { \& devices, accessible } \\
\text { electronic repository, facility } \\
\text { to search, select, present \& } \\
\text { share artefacts, collaboration, } \\
\text { facility to transport artefacts to } \\
\text { new systems } \\
\text { Challenges: lack of resources, } \\
\text { staff engagement, technology } \\
\text { functionality \& reliability, } \\
\text { need for a holistic rather than } \\
\text { ad hoc approaches, lack of } \\
\text { evidence on student learning, } \\
\text { lack of understanding of the } \\
\text { 'why’ and 'how' of } \\
\text { ePortfolios, lack of cultural } \\
\text { readiness, lack of staff } \\
\text { confidence }\end{array}$ & $\begin{array}{l}\text { Leadership roles: } \\
\text { - Who should lead the implementation of ePortfolios in } \\
\text { the business education curriculum? Should it be a faculty } \\
\text { or institutional decision? } \\
\text { - What approaches can be adopted to lead change } \\
\text { management around the implementation of ePortfolios? } \\
\text { - What incentives, workload allocations and training can } \\
\text { be provided to support effective implementation of } \\
\text { ePortfolios? Where and how is staff capacity building } \\
\text { facilitated? } \\
\text { ePortfolios as an approach to learning and } \\
\text { development: } \\
\text { - Why choose an ePortfolio over other approaches? } \\
\text { - How do academics design ePortfolios for specific } \\
\text { purposes, i.e. aligned to pedagogy and/or in addressing } \\
\text { different professional capabilities in different areas of } \\
\text { the curriculum? } \\
\text { - How do we evaluate the benefits and costs of using } \\
\text { ePortfolios in business education? } \\
\text { - How do we identify and navigate/mitigate the challenges } \\
\text { of using ePortfolios in the business education } \\
\text { curriculum? } \\
\text { - How do we facilitate students transporting their } \\
\text { ePortfolios to accommodate their ongoing personal } \\
\text { learning, employment and career development? } \\
\text { - How can we use ePortfolios to best assess professional } \\
\text { - Hssessment design using ePortfolios: } \\
\text { - What to assess in the business education curriculum } \\
\text { through ePortfolio? } \\
\text { business education in the business education curriculum? } \\
\text { education curriculum? } \\
\text { regimes, of the quality of ePortfolio work to students? }\end{array}$ & $\begin{array}{l}\begin{array}{l}\text { Resources to } \\
\text { assist ePortfolio } \\
\text { design }\end{array} \\
\text { Case studies of } \\
\text { institutional use: } \\
\text { across whole } \\
\text { course, across } \\
\text { discipline major, in } \\
\text { capstone units; } \\
\text { examining } \\
\text { purpose, context, } \\
\text { stakeholders, } \\
\text { design \& } \\
\text { implementation, } \\
\text { evaluation, } \\
\text { improvements } \\
\text { Staff and student } \\
\text { training and } \\
\text { support materials }\end{array}$ \\
\hline
\end{tabular}

\section{Conclusion}

ePortfolios are currently not a mainstream pedagogic approach for developing and evidencing professional capabilities in business education. Business education leaders' perspectives reinforced the marginal status of the ePortfolio in the business education landscape. Clearly, ePortfolios have far greater traction in other professional fields that might be seen to be more homogeneous in nature. The very diversity of business education as a field, with its various constituent disciplines and curriculum designs, does however open up possibilities for greater use of ePortfolios to develop and assess valued professional capabilities. Academic leaders see room for improvement in satisfactorily addressing these professional capabilities. There is potential to match professional capabilities with valued forms of business education pedagogies with and through the astute adoption of ePortfolios in the curriculum. The challenges in achieving this type of alignment cannot be underestimated, based on leadership perspectives on constraints. Various internal and external environmental factors that impact business education will continue to place ePortfolios firmly on the agenda for adoption. The paper has outlined a framework to assist parties in moving to ePortfolio implementation more systematically and effectively in response to such forces. 


\section{Acknowledgements}

The authors wish to thank the lead university, Deakin University, and the partner institutions (Macquarie University, University of Southern Queensland) for their generous contribution to this project, as well as all those participants who contributed to the data collection processes. Support for this publication has been provided by the Office for Learning and Teaching (OLT), an initiative of the Australian Government's Department of Education and Training. The views expressed in this publication do not necessarily reflect the views of the OLT.

\section{References}

Allan, C. N., \& Cleland, B. (2012) Embedding eportfolios in teacher education: Lessons from a multiyear implementation. In M. Brown, M. Hartwell, \& T. Stewart (Eds.), Proceedings of ascilite Wellington 2012: Future challenges, sustainable futures (pp. 197-201).

Andre, K., \& Heartfield, M. (2011). Nursing and midwifery portfolios: Evidence of continuing competence. Sydney: Elsevier Australia.

Australian Business Deans Council (2008). Scoping report: Business as usual. Sydney: The Carrick Institute for Learning and Teaching in Higher Education. Retrieved from http://www.google.com.au/url?sa=t\&rct=j\&q=\&esrc=s\&source=web\&cd=1\&ved=0ahUKEwjhmKytq KHMAhUjHKYKHb3ABCIQFggcMAA\&url=http\%3A\%2F\%2Fwww.graduateskills.edu.au\%2Fwpcontent\%2Fuploads\%2F2010\%2F08\%2FGrants_DBI_ABDC-Freeman-Business-FinalReport_March27 20

Australian Business Deans Council (2012). Academic standards for marketing in the Australian higher education context. Canberra: Marketing Learning Outcomes Working Party. Retrieved from http://www.abdc.edu.au/data/Marketing_LS/Marketing_Learning_Standards___September_2012.pdf

Australian Business Deans Council (2013). Economics learning standards for Australian higher education. Canberra: Economics Learning Standards Working Party. Retrieved from http://www.abdc.edu.au/data/economics_LS/Economics_Learning_Standards_-_November_2013.pdf

Australian Business Deans Council (2014). Academic learning standards for finance in the Australian higher education context. Canberra: Finance Learning Standards Working Party. Retrieved from http://www.abdc.edu.au/data/Finance_Learning_Standards/Finance_Learning_Standards__November_2014.pdf

Australian Computer Society (2013). Skills framework for the information age (SFIA). Retrieved from https://www.acs.org.au/sfia-certification

Australian ePortfolio Project (2008). ePortfolio use by university students in Australia: Informing excellence in policy and practice final project report. Sydney: Australian Learning and Teaching Council, Department of Education, Employment and Workplace Relations. Retrieved from http://olt.gov.au/resource-eportfolio-use-qut-2008

Australian ePortfolio Project (2009). ePortfolio concepts for employers, professional bodies and career services. Sydney: Australian Learning and Teaching Council. Retrieved from http://olt.gov.au/resource-eportfolio-use-qut-2009

Biggs, J., \& Tang, C. (2011). Teaching for quality learning at university. What the student does. Buckingham, England: Society for Research into Higher Education \& Open University Press.

Coffey, U., \& Ashford-Rowe, K. (2014). The changing landscape of ePortfolios: A case study in one Australian University. Australasian Journal of Educational Technology, 30(3), 284-294. http://dx.doi.org/10.14742/ajet.v30i3.199

Coleman, K., Cox, J., Das, M., Flood, A., Polly, P., Thai, T., \& Yang, J. L. (2012). Eportfolios in the sciences: The role of reflection as students build professional skills and career readiness. In M. Brown, M. Hartwell, \& T. Stewart (Eds.), Proceedings of ascilite Wellington 2012: Future challenges, sustainable futures (pp. 219-222).

Faulkner, M., Aziz, S. M. Waye, V., \& Smith, E. (2013). Exploring ways that ePortfolios can support the progressive development of graduate qualities and professional competencies. Higher Education Research and Development, 32(6), 871-887. http://dx.doi.org/10.1080/07294360.2013.806437

Freeman, M. (2010). Accounting: Learning and teaching Academic standards statement. Sydney: Australian Learning and Teaching Council. Retrieved from http://www.olt.gov.au/resourceaccounting-ltas-statement-altc-2010 
Hallam, G., \& Creagh, T. (2010). ePortfolio use by university students in Australia: A review of the Australian ePortfolio Project. Higher Education Research \& Development, 29(2), 179-193. Retrieved from http://eprints.qut.edu.au/31667/2/31667.pdf

Harper, W., McCowan, C., Hauville, K., Moody, K., \& Chorazyczewski, D. (2007, March). Voluntary or compulsory: Using a variety of approaches and models to implement the student e-Portfolio across 40,000 students at QUT. Paper presented at ePortfolio Australia, RMIT University, Melbourne. Retrieved from https://www.researchgate.net/publication/27467576_Voluntary_or_compulsory_Using_a_variety_of approaches_and_models_to_implement_the_Student_e-Portfolio_across_40000_students_at_QUT

Hart Research Associates (2013). It takes more than a major: Employer priorities for college learning and student success. An online survey among employers conducted on behalf of the Association of American Colleges and Universities. Liberal Education, 99(2). Retrieved from https://www.aacu.org/publications-research/periodicals/it-takes-more-major-employer-prioritiescollege-learning-and

Housego, S., \& Parker, N. (2009). Positioning ePortfolio in an integrated curriculum. Education + Training, 51(5/6), 408-421. http://dx.doi.org/10.1108/00400910910987219

Joyes, G., Gray, L., \& Hartnell-Young, E. (2010). Effective practice with e-portfolios: How can the UK experience inform implementation? Australasian Journal of Educational Technology, 26(1), 15-27. http://dx.doi.org/10.14742/ajet.v26i1.1099

Lambert, S., \& Corrin, L. (2007). Moving towards a university wide implementation of an ePortfolio tool. Australasian Journal of Educational Technology, 23(1), 1-16. http://dx.doi.org/10.14742/ajet.v23i1.1270

Lee, M., \& Pohio, L. (2012). An e-portfolio theoretical approach for provisionally registered teachers. In M. Brown, M. Hartwell, \& T. Stewart (Eds.), Proceedings of ascilite Wellington 2012: Future challenges, sustainable futures (pp. 550-559).

Lillyman, S., \& Merrix, P. (2012). Nursing \& health survival guide portfolios and reflective practice. Essex, UK: Pearson Education.Okoro, E., Washington, M. C., \& Cardon, P. W. (2011). ePortfolios in business communication courses as tools for employment. Business Communication Quarterly, 74(3), 347-351. http://dx.doi.org/10.1177/1080569911414554

Ngo. L., Watty, K., McKay. J., Holt, D., Kavanagh, M., McGuigan, N., \& Leitch, S. (2014). Implementing ePortfolios in an Australian business education curriculum: Layer by layer. Poster presentation at the EPortfolio Forum and Workshops. EPortfolio Australia, Melbourne, Australia.

Papadopoulos, T., Taylor, T., Fallshaw, E., \& Zanko, M. (2011). Engaging industry: Embedding professional learning in the business curriculum final report. Sydney: Australian Learning and Teaching Council. Retrieved from http://www.olt.gov.au/resource-engaging-industry-embedding-vu$\underline{2011}$

Reed, S. (2011). Successful professional portfolios for nursing students. Exeter, UK: Learning Matters.

Shroff, R. H., Trent, J., \& Ng, E. M. W. (2013). Using e-portfolios in a field experience placement: Examining student-teachers' attitudes towards learning in relationship to personal value, control and responsibility. Australasian Journal of Educational Technology, 29(2), 143-160. http://dx.doi.org/10.1234/ajet.v29i2.51

Swan, G. (2009). Examining barriers in faculty adoption of an e-portfolio system. Australasian Journal of Educational Technology, 25(5), 627-644. http://dx.doi.org/10.14742/ajet.v25i5.1112

Taylor, J., Dunbar-Hall, P., \& Rowley, J. (2012). The e-portfolio continuum: Discovering variables for eportfolio adoption within music education. Australasian Journal of Educational Technology, 28(8), 1362-1381. http://dx.doi.org/10.14742/ajet.v28i8.776

Waye, V., \& Faulkner, M. (2011). E-Portfolios and legal professional attributes._In S. Kift, M. Sanson, J. Cowley, \& P. Watson (Eds.). Excellence and innovation in legal education (pp. 239-268). Chatswood, Sydney: LexisNexis Butterworths.

Whitelaw, P. A., Benckendorff, P., Gross, M. J., Mair, J., \& Jose. P. (2015). Tourism, hospitality \& events learning and teaching academic standards final report. Sydney: Office for Learning and Teaching. Retrieved from http://www.olt.gov.au/resource-tourism-hospitality-and-events-learning-and-teachingacademic-standards-2015

Williams, A., Simmons, C., Levett-Jones, T., Sher, W., \& Bowen, L. (2012). Facilitating work integrated learning (WIL) through skills-enabled e-portfolios in construction and nursing final report. Sydney: Office for Learning and Teaching, Department of Industry, Innovation, Science, Research and Tertiary Education. Retrieved from http://www.olt.gov.au/project-facilitating-wil-eportfolios-uon$\underline{2009}$ 
Woodley, C., \& Sims, R. (2011). EPortfolios, professional development and employability: Some student perceptions. Campus-Wide Information Systems, 28(3), 164-174. http://dx.doi.org/10.1108/10650741111145698

Corresponding author: Associate Professor Dale Holt, dale.holt@deakin.edu.au

Australasian Journal of Educational Technology (c) 2016.

Please cite as: Holt, D., McGuigan, N., Kavanagh, M., Leitch, S., Ngo, L., Salzman, S., Watty, K. \& McKay, J. (2016). Academic leaders' perspectives on adopting ePortfolios for developing and assessing professional capabilities in Australian business education. Australasian Journal of Educational Technology, 32(5), 1-18. http://dx.doi.org/10.14742/ajet.2666 